\title{
Description of Implementation of Self-Regulated Learning on Student at The University of $X$
}

\author{
Yan Andre Peranginagin ${ }^{1 *}$, Budi Sulaeman², Antonina Pantja Juni Wulandari \\ 1,2,3 Psychology Department, Faculty of Humanities \\ Bina Nusantara University \\ Jakarta 11480, Indonesia \\ yperanginangin@binus.edu; bsulaeman@binus.ac.id; yunwulan@binus.edu \\ *Correspondence: yperanginangin@binus.edu
}

\begin{abstract}
This research aims to provide a description regarding the implementation of Self-Regulated Learning on students at the University of $X$. This research was organized with quantitative methods with types of descriptive. Sampling method on this research using the technique of convenience with the number of participants of 110 students of University consist of 48 males and 62 females. Measurement of Self-Regulated Learning conducted using questionnaires which done by researchers based on 3 phases of Self-Regulated Learning, which are: (1) Forethought, (2) Performance and (3) Self-reflection. The result of this research showed that applying on the first phases which is the stage of Forethought relatively low with the gain of score of 2.62 compared to an average score of 2.82. However, the second phases, which is the stage of performance relatively high with the gain of score above average which is 2.90. the implementation of the third phases which the self-reflection quite high with the score of 2.94. On the research also found the relationship between Grade Point Average (GPA) and the implementation of the 3 phases of Self-Regulated Learning, which is the higher GPA score earned by students, the more optimal the implementation of 3 cycles of Self-Regulated Learning.
\end{abstract}

Keywords: Self-regulated learning; Academic achievement; Students.

\section{INTRODUCTION}

\section{Research Background}

Students are people who study in College (Departmen Pendidikan Nasional, 2016). Other than that, based on the decision of the Law of the Republic of Indonesia number 12 of 2012 concerning Higher Education explained that students are students at the level of higher education. When carrying out the role as a learner in college, each student must have the duties and responsibilities which are developing themselves by learning, seeking the truth of scientific moreover mastered the field of study which was occupied in order to become scientists, practitioners and cultured professionals. Meanwhile, as learners, students also have demands for optimal academic achievement.

Academic achievement is an interesting study particularly in the field of educational psychology. This is because academic achievement is a measurement of somebody's success in the academic world (El-Anzi, 2005). Meanwhile, academic achievement is formed by two factors, which are internal factors and external factors. The internal factors are psychological factors which consist of (a). intelligence (intellectual capacity), (b). attitude (c). interest, (d). talent, (e). motivation, (f). ability to manage himself in learning and (g). physiological factors. External factors include (a.) Parenting, (b). learning environment, (c). learning facilities and (d). quality of educator (Woolfolk, 2010).

The researchers found data from the unit of Student Advisory \& Support Center at University X showed that of 450 active students, $34 \%$ of them or 153 students were NR (non-regular) students. This non-regular 
category is organized based on three criteria, which are (a) students with a cumulative grade index below 2.00 (from 0 - 4.00), (b) the number of credits taken is not in accordance with the current semester and (c) students who meet both of these criteria. Absolutely, this condition needs to be cared well because if it is not well handled immediately it will be a problem, which are: decreased learning motivation, students cannot take thesis because there are requirements for a minimum grade point average and risks of expelled from the campus or drop-out.

Based on surveys and interviews conducted on 5 non-regular students in Department X of University X there were five factors that affect the low student achievement, which are (a). do not have regular time to study at home, (b). the department selected is not the actual department they interest, (c). do not have the objectives to be accomplished, (d). take the college because of the domination of external factors for example parental demand and (e). having difficulty in managing time. Based on those five factors above, in the context of Educational Psychology there is a conclusion that students are not optimal in implementing.

Self-Regulated Learning (SRL) is also interpreted as an ability to encourage a person's will to set goals in his life, plan strategies and evaluate and modify the behavior he apply (Schunk, 2005). Meanwhile, there are three main principles of the importance to develop Self-Regulated learning skills in studying. First, Self-Regulated Learning is actually oriented in developing the ability to manage themselves in learning with students. Second, posses a positive correlation toward increased motivation and achievement in students. Third, able to develop a long lasting learning skills (Susetyo \& Khumara, 2012). In its implementation, Self-Regulated Learning is divided in three phases (Zimmerman, 2000). which are forward thinking or forethought, performance and stage of selfreflection.

In a study of research conducted by Zimmerman (2001), shows a Self-Regulated Learning has a significant correlation with increasing of academic achievement. Meanwhile, according to Schunk, Pintrich and Meece (2012) shows that students who have not been able to achieve optimal academic performance are caused by the failure of individuals to regulate themselves in learning. This is supported by Woolfok (2010) which describes one of the internal factors in an individual who determines academic achievement, which is the ability to conduct self-regulation in learning.

According to Omrod (2003), one of the negative effects which also be perceived by individuals who fail to develop self-regulation properly is the emergence of aggressive behavior in these individuals. Individuals who are able to apply self-regulation optimally will experience a positive impact on themselves. According to Omrod (2003), individuals who are able to optimize self-regulation effectively will be able to control behavior very well and reduce maladaptive behavior, so that they are expected to be able to show an appropriate behavior.

Based on the importance of the ability to apply Self-Regulated Learning to students as well as referring to previous research which showed less optimal performance on students due to failure to manage themselves in learning. Moreover, considering the negative impact which will be received by students because of their lack of ability to implement Self-Regulated Learning, this research is an important thing to do. The purpose of this research is to obtain a description of the quality of the implementation of the three phases of Self-Regulated Learning which have been carried out by students at University X.

\section{Literature Review}

Self-Regulated Learning (SRL) is also interpreted as an ability to encourage a person's will to set goals in his life, plan strategies and evaluate and modify the behavior he apply (Schunk, 2005). SRL is divided in three phases (Zimmerman, 2000). which are forward thinking or forethought, performance and stage of self-reflection. The three stages should be carried out by students in order to obtain optimal results in studying. The stage of forward thinking consists of two parts, which are analysis of task and motivation. Self motivation consists of individual beliefs about learning which is self-efficacy, expectations of results, intrinsic of interest and orientation towards learning goals (Zimmerman, 2000).

The stage of performance consists of two major groups which are self-control and self-observation (Zimmerman, 2000). Self-control refers to the determination of a certain method or strategy that has been chosen at the stage of thinking. Meanwhile, self-observation refers to recording oneself to a personal occurrence to obtain the cause of the occurrence.

The stage of self-reflection consists of two main processes which are self-judgment and self-reaction (Zimmerman, 2000). Self-judgment is the process of comparing the results of self-observation of performance with previous stages of performance. Another form of self-judgment is attributions of causes that show beliefs about the causes of success or failure. The form of self-reaction consists of self-satisfaction and adaptive or 
defensive responses. Increased self-satisfaction will increase motivation as well. However, a decrease in selfsatisfaction will tear down the learning efforts.

\section{Problem Formulation}

Based on data from the Student Advisory \& Support Center at the University of X, there were $34 \%$ or about 153 of 450 active students in one of the department who had less optimal learning outcomes that they were called non-regular students. When explored further through interviews with five non-regular students who had less optimal learning outcomes, the results of the interviews showed that the students had not been able to implement Self-Regulated Learning optimally. it is indicated by (a). they do not have regular time to study at home, (b). the department chosen is not the department they are interested in, (c). they do not have the goals to be achieved, (d). they take the level of college because of external factors which is parental requests and (e). having difficulty in managing time. The results of previous research prove that Self-Regulated Learning has a positive correlation with academic achievement. Seeing the importance of aspect of the Self-Regulated Learning for students as the capital to achieve optimal academic achievement, this study will focus on how students can apply the SelfRegulated Learning at University X.

\section{Research Objectives}

Regarding the problems that have been formulated, this research aims to get an description about the implementation of Self-Regulated Learning to students at university X.

\section{METHODS}

This quantitative study was conducted using a descriptive to gain an overview of the implementation of Self-Regulated Learning to students at university X.

\section{Participants}

The number of samples in this research were 110 active students. Participants consist of regular and nonregular students at the University of X which consist of 48 males respondents and 62 females respondents with range of age from 19-25 years. The sampling technique used convenience sampling. Convenience sampling is one of the types of non-probability which determines the appropriate sample which is directly encounter with the respondent and given a Self-Regulated Learning measure.

\section{Measures}

Assessment of Self-Regulated Learning variables in this research was carried out using a questionnaire which was prepared independently by the researcher. The preparation of this measuring instrument is based on three phases of Self-Regulated Learning (Zimmerman, 2000) which are (1) forethought, (2) implementation and (3) evaluation. This questionnaire was organized using a Likert scale and consist of 42 items. In June 2017, a trial of the Self-Regulated Learning measurement was conducted to 32 students.

The following are examples of Self-Regulated Learning items based on three phases: (1) forethought: I know how to solve difficulties while doing college assignments; I know the reason for choosing majors. (2) implementation: I am able to manage time well; I understand the learning style; I easily leave my task when I'm bored, (3) evaluation: I feel satisfied with the results of my study; I learned from every failure I experienced

From the results of the reliability test through consistent internal, cronbach alpha, the results of the reliability scores: 0.793 . Meanwhile, based on the results of the validity test using corrected item total correlation, showing 30 items were declared valid with a range of validity scores: $0.31-0.57$. However, 12 items are invalid. As an act on items which are invalid, revisions are made to be included in the questionnaire to be distributed in the field study. 


\section{RESULT AND DISCUSSION}

\section{Result}

\section{Demographic Data}

Table 1. Data Based On Sex

\begin{tabular}{ccc}
\hline Sex & Quantity & Percentage \\
\hline Male & 48 & $43.6 \%$ \\
\hline Female & 62 & $56.4 \%$ \\
\hline Total & 110 & $100 \%$ \\
\hline
\end{tabular}

Table 1 shows based on gender, 48 persons (43.6\%) were male. Meanwhile, 62 other persons $(56.4 \%)$ were female.

\begin{tabular}{ccc}
\multicolumn{3}{c}{ Table 2. Data Based On Level of Semester } \\
\hline Semester & Quantity & Percentage \\
\hline 1 & 17 & $15.4 \%$ \\
\hline 3 & 59 & $53.6 \%$ \\
\hline 5 & 26 & $23.6 \%$ \\
\hline 7 & 7 & $6.36 \%$ \\
\hline 11 & 1 & $0.90 \%$ \\
\hline Total & 110 & $100 \%$ \\
\hline
\end{tabular}

Table 2 shows based on level of semester, 17 students are at semester 1.59 other students are in semester 3 . 26 students in semester 5.7 students in semester 7 and 1 student in semester 11.

Table 3. Data Based on Grade Point Average

\begin{tabular}{ccc}
\hline $\begin{array}{c}\text { Grade Point } \\
\text { Average }\end{array}$ & Quantity & Percentage \\
\hline$<2.00$ & 23 & $20.9 \%$ \\
\hline $2.00-3.00$ & 58 & $52.7 \%$ \\
\hline$>3.00$ & 24 & $21.8 \%$ \\
\hline without explanation & 5 & $4.6 \%$ \\
\hline Total & $\mathbf{1 1 0}$ & $\mathbf{1 0 0 \%}$ \\
\hline
\end{tabular}

Table 3 shows based on the Grade Point Average (GPA), 23 students had a Grade Point Average score of less than $2.00(<2.00) .58$ other students have a Grade Point Average score range between 2.00 - 3.00. Meanwhile, 24 students have a Grade Point Average above 3.00 (>3.00). However, there are 5 students who did not write down the Grade Point Average statement.

\section{Results of the Study}

According to the objective of this study, this study presents the implementation of Self-Regulated Learning to students at university X. The followings are data on the implementation of Self-Regulated Learning of 110 students participating in this study.

Table 4. Result of Analyses of 3 Phases SRL

\begin{tabular}{cccc}
\hline Phases of SRL & Score Gained & Average Score & Percentage \\
\hline Forethought & 2.62 & 2.82 & Low \\
\hline Performance & 2.90 & 2.82 & High \\
\hline Self-Reflection & 2.94 & 2.82 & High \\
\hline
\end{tabular}

The results of this research regarding the implementation of 3 phases of Self-Regulated Learning to students at the University of X show: (1). The implementation in the first phases which is fore throught is low because the score obtained is below the average score of 2.62 compared to the average score which is 2.82. (2) Implementation 
in the second phases, which is performance is quite high or optimal because the score obtained is higher than the average score 2.90. (3). In the third phases, self-reflection. A score of 2.94 is obtained. The score obtained is high because it is above the average score of 2.82 . This shows that the implementation of the third phase is performed well by the participants.

Table 5. Result of one-way anova GPA and SRL

\begin{tabular}{cccccc}
\hline \multicolumn{7}{c}{ ANOVA } \\
\hline & Sum of Squares & df & Mean Square & F & Sig. \\
\hline Between Groups & 7234,574 & 2 & 3617,287 & 29,292 &, 000 \\
\hline Within Groups & 12102,179 & 98 & 123,492 & & \\
\hline Total & 19336,752 & 100 & & & \\
\hline
\end{tabular}

Based on the results of one-way ANOVA test between groups showed a significant score of: $0,000(<0.05)$. This means that there are differences in the average score between groups. Participants with a high GPA who have the ability to apply Self-Regulated Learning are also optimal.

\section{Discussion}

The results of data analysis show that the Self-Regulated Learning implementation in the second phases (performance) dan the third phases (self-reflection) are optimal, it shows that the implementation of the second phase dan the third phase are performed well by the participants. On the second phases (performance), the learner manages their own learning through the self-control process and should be paired with self-observation (Song, 2017). This reflects that when learning something, participants observe and monitors their learning process.

Furthermore, on the third phases (self-reflection) consists of two main processes which are self-judgment and self-reaction (Zimmerman, 2000). According to Song (2017), the self-judgment process includes self-evaluation which also encompasses the cause analysis, such as thinking about what caused the success or failure of learning. This reflects that with the self-evaluation and analysis, the participants are able to diagnose whether they achieved their learning goal or not, and, importantly, to measure their self-satisfaction level.

While, in the first phases (forethought) has not been optimally applied by the participants. This reflects that when participants complete their coursework, they have not previously set a plan and set a goal. According to Song (2017), in forethought phases, the self-regulated learner analyzes a task prior to learning something new, and the most important thing in this step is goal setting. A learner might even start with setting their learning goal, but in many cases, it's not followed by a specific plan. Thus, strategic planning should be done when setting a learning goal (Song, 2017).

\section{CONCLUSION}

The implementation of Self-Regulated Learning in all participants is quite optimal. It is indicated by the implementation of the second phases (performance) and the third phases (self- reflection) is quite optimal. It is just, in the first phases, which is forethought has not been optimally applied by the participants.

With low forethought, students easily give up when facing difficulties in studies because they are not based on specific goals. This is also influenced by the low self-efficacy. Meanwhile, learning objectives for students are not oriented towards mastering the material. Moreover, participants with a high grade point average have optimal abilities in implementing Self-Regulated Learning. 


\section{REFERENCES}

Departemen Pendidikan Nasional. (2016). Kamus besar bahasa Indonesia, 5th ed. (Jakarta: Balai Pustaka).

El-Anzi, F.O. (2005). Academic achievement and its relationship with anxiety, self esteem, optimism, and pessimissm in kuwaiti students. Social Behavior and Personality. 33(1), 95-104.

Ormrod, J.E., (2003). Educational psychology: developing learners, 4th ed. (New Jersey: Pearson Education inc).

Schunk, D. H. (2005). Self-regulated learning: the educational legacy of paul pintrich. Journal of Educational Psychology, 40(2), 85-94.

Schunk, D. H., Pintrich, J. L. \& Meece. (2012). Motivasi dalam pendidikan, teori penelitian dan aplikasi, 3rd ed. Tjo. E (Penerj). (Jakarta: Indeks).

Song, D. (2017). Self-regulated learning. 3 Phases. Einbrain. https://einbrain.com/1773

Susetyo, Y. F. \& Khumara, A. (2012). Orientasi tujuan, atribusi penyebab dan belajar berdasar regulasi diri. Jurnal Psikologi, 39(1), 95-111.

Woolfolk, A. (2010). Educational psychology. Upper saddle river, (NJ: Pearson Education International).

Zimmerman, B. J. (2001). Theories of self-regulated learning and academic achievement: An overview and analysis. Jurnal of Educational Psychology, 25(1), 3-17.

Zimmerman, B. J. (2000). Attaining self-regulation: A social cognitive perspective. In M. Boekaerts, P.R. Pintrich, and M. Zeidner (Eds.) Handbook of self-Regulation (pp. 13-39). (San Diego,CA, US: Academic). 